\title{
A Simple Method to Compute Fiscal Multipliers
}




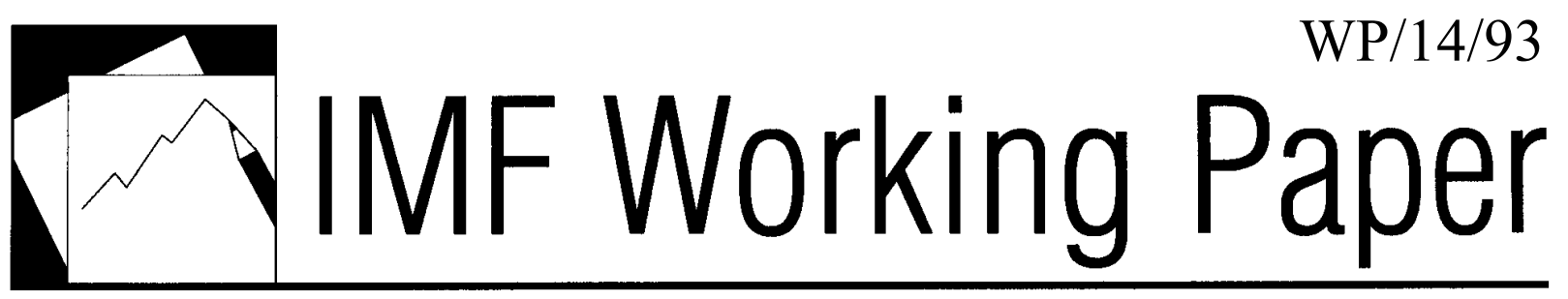

A Simple Method to Compute Fiscal Multipliers

Nicoletta Batini, Luc Eyraud, and Anke Weber 


\title{
IMF Working Paper
}

Fiscal Affairs Department

\section{A Simple Method to Compute Fiscal Multipliers ${ }^{1}$ Prepared by Nicoletta Batini, Luc Eyraud, and Anke Weber ${ }^{2}$}

Authorized for distribution by Julio Escolano

June 2014

\section{This Working Paper should not be reported as representing the views of the IMF.} The views expressed in this Working Paper are those of the author(s) and do not necessarily represent those of the IMF or IMF policy. Working Papers describe research in progress by the author(s) and are published to elicit comments and to further debate.

\begin{abstract}
Fiscal multipliers are important tools for macroeconomic projections and policy design. In many countries, little is known about the size of multipliers, as data availability limits the scope for empirical research. For these countries, we propose a simple method-dubbed the "bucket approach" — to come up with reasonable multiplier estimates. The approach bunches countries into groups (or "buckets") with similar multiplier values, based on their characteristics. It also takes into account the effect of some temporary factors, such as the state of the business cycle.
\end{abstract}

JEL Classification Numbers: E32, E62, H5

Keywords: Fiscal policy, fiscal multipliers

Authors’ E-Mail Addresses: Nicoletta.batini@tesoro.it; LEyraud@imf.org; AWeber@imf.org

\footnotetext{
${ }^{1}$ The paper partly draws from IMF (2013). We thank Daniel Leigh for extensive discussions and comments. The paper also benefited from inputs received from Chadi Abdallah, Yasser Abdih, David Amaglobeli, Juliana Araujo, Elif Arbatli, Tamon Asonuma, Said Bakhache, Tamim Bayoumi, Martin Cerisola, Chris Erceg, Josh Felman, Lorenzo Forni, Philip Gerson, Martine Guerguil, Charleen Gust, Vikram Haksar, Dora Iakova, Deniz Igan, Martin Kaufman, Amina Lahreche, Yanliang Miao, Dirk Muir, Papa N'Diaye, Frantisek Ricka, Mike Seiferling, Vahram Stepanyan, Hajime Takizawa, Ruud Vermeulen, Bruno Versailles, and Susan Yang.

${ }^{2}$ Nicoletta Batini: Ministry of Economy and Finance of Italy; Luc Eyraud and Anke Weber: IMF.
} 
Abstract $\underline{2}$

I. Introduction

II. What do we Know About the Size, Persistence, and Determinants of Fiscal Multipliers? ..므

A. Size of Fiscal Multipliers

B. Determinants of the Size of Multipliers

C. Persistence of Fiscal Multipliers

III. The Bucket Approach ..... $\underline{14}$

A. Main Steps $\underline{14}$

B. Illustration $\underline{18}$

C. Caveats and Extensions $\underline{18}$

IV. Conclusions. $\underline{19}$

Tables

1. Narrative Approach: First-Year Tax Multipliers

2. Narrative Approach: First-Year Spending Multipliers

3. Multipliers in EMEs and LICs

4. Fiscal Multipliers over the Business Cycle.................................................................11

5. Government Spending Multipliers and the Zero Lower Bound ....................................12

6. Ranges of First-Year Overall Multipliers …...................................................... $\frac{16}{16}$

7. Scoring Based on Structural Characteristics........................................................... $\frac{18}{18}$

8. Derivation of First-year Multiplier Using the Bucket Approach ......................................18

Boxes

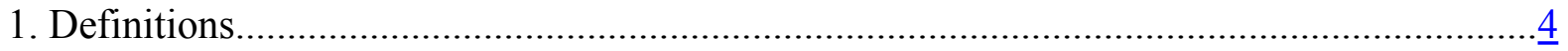

A.1.1. Pros and Cons of Empirical Versus Model-Based Estimates ....................................

Appendices

1. Multiplier Estimation Techniques in the Literature .....................................................21

2. Fiscal Multipliers by Instrument and Confidence Effect ............................................23

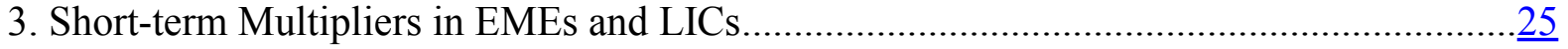

Appendix Tables

A.2.1 Empirical Studies: Short-run Multipliers by Instrument........................................24

A.3.1. Empirical Studies: Short-Term Multipliers in EMEs/LICs ................................... 25

A.3.2 Model-based Estimates of Short-Term Multipliers …...........................................

Appendix Figure

A.2.1. Average of DSGE Models: First-Year Multipliers .................................................23

References 


\section{INTRODUCTION}

Fiscal multipliers measure the short-term impact of discretionary fiscal policy on output. They are usually defined as the ratio of a change in output to an exogenous change in the fiscal deficit with respect to their respective baselines (Box 1). ${ }^{3}$

\section{Box 1. Definitions}

Fiscal multipliers can be measured in several ways. Generally, they are defined as the ratio of a change in output $(\Delta \mathrm{Y})$ to a discretionary change in government spending or tax revenue $(\Delta \mathrm{G}$ or $\Delta \mathrm{T})$ (Spilimbergo and others, 2009). Thus, the fiscal multiplier measures the effect of a $\$ 1$ change in spending or a $\$ 1$ change in tax revenue on the level of GDP.

Two multipliers are commonly used (focusing on expenditure):

$$
\text { Impact multiplier }=(\Delta \mathrm{Y}(\mathrm{t})) /(\Delta \mathrm{G}(\mathrm{t}))
$$

Multiplier at horizon $\mathrm{i}=(\Delta \mathrm{Y}(\mathrm{t}+\mathrm{i})) /(\Delta \mathrm{G}(\mathrm{t}))$

where $t$ can be a quarter or a year depending on the frequency of the data that is used in the study.

The "overall" multiplier describes the output response to an unspecified fiscal shock, while the "revenue" ("spending") multiplier relates output to a discretionary change in revenue (spending).

Better estimation and use of multipliers can play a key role in ensuring macroeconomic forecast accuracy. Many countries experienced a dramatic turnaround in their fiscal position during the crisis, shifting from stimulus to consolidation. In this context of large-scale fiscal actions, GDP growth may be primarily driven by fiscal policy. Thus it is essential to measure accurately the relationship between these two variables in order to plan and forecast the effect of policy actions. For example, Blanchard and Leigh (2013) find that the underestimation of fiscal multipliers early in the crisis contributed significantly to growth forecast errors.

Multipliers are also important elements to take into consideration in policy advice and design. ${ }^{4}$ Underestimating multipliers may lead countries to set unachievable fiscal targets, and miscalculate the amount of adjustment necessary to curb their debt ratio (Eyraud and

\footnotetext{
${ }^{3}$ This paper refers to multipliers as one-year multipliers unless otherwise stated. In addition, all the following terms are synonyms: (exogenous) fiscal shock, fiscal impulse, and discretionary change in fiscal policy.

${ }^{4}$ Multipliers are only one of the many factors that need to be considered in setting fiscal policy. This paper focuses on the short-term impact of fiscal measures on GDP. Short-term fiscal multipliers provide little guidance about medium- to long-term effects, and fiscal sustainability. By focusing on GDP, they are silent on other important variables, such as employment, social outcomes, and income distribution.
} 
Weber, 2012, 2013). This could affect the credibility of fiscal consolidation programs. In addition, authorities may engage in repeated rounds of tightening in an effort to make fiscal variables (balance, debt) converge to official targets, undermining confidence; and setting off a vicious circle of slow growth, deflation, and further tightening.

Despite their expected benefits, multipliers are not widely used by economists in operational work. The main reason is that their estimation is tricky. In particular, it is difficult to isolate the direct effect of fiscal measures on GDP, because of the two-way relationships between these variables. Spending and taxes typically react automatically to the business cycle through so-called "automatic stabilizers." They also respond to the cycle in a discretionary way; for instance a countercyclical policy may raise tax rates and cut spending when the output gap increases. Researchers have tried to address this circularity problem by focusing on the subset of exogenous fiscal shocks. ${ }^{5}$ However, there is no commonly agreed methodology to identify such shocks or to extract the exogenous component from observed fiscal outcomes (Appendix 1). As a result, there is little consensus in the literature on the size of multipliers.

In addition, data availability limits the scope for estimating multipliers. Econometric and model-based methods are demanding in terms of data requirements. For instance, the estimation of structural vector autoregressive models (SVAR) necessitates high-frequency data and sufficiently long time series. Long quarterly series do not exist in many advanced economies (AEs), as well as in most emerging market economies (EMEs) and low-income countries (LICs).

For countries where no reliable estimate is available, this paper proposes to "guesstimate" multipliers with a method that we dub the "bucket approach." The general idea is to bunch countries into groups (or "buckets") that are likely to have similar multiplier values based on their characteristics. To our knowledge, this paper is the first one to offer practical guidance on multipliers in countries with limited data availability. Although it is not its primary purpose, our approach can also be used as a useful cross-check in countries where estimates are already available.

The paper is organized as follows. Section II reviews the literature, proposing specific ranges of multipliers in AEs, EMEs and LICs, and identifying the main determinants. These ranges and determinants are used in Section III to derive multipliers with the bucket approach. Section IV presents some conclusions.

\footnotetext{
5 In the literature, the term "exogenous shock" refers to a change in spending or revenue that is not induced by the macroeconomic environment.
} 


\section{What do We Know About the Size, Persistence, And Determinants OF FisCAL MUlTipliers?}

This section summarizes the main findings of the multiplier literature. These results are subsequently used in the bucket approach to define reasonable ranges of multipliers and identify a set of characteristics affecting their size.

\section{A. Size of Fiscal Multipliers}

\section{Advanced Economies}

DSGE simulations and SVAR models, developed since the early 1990s, suggest that firstyear multipliers generally lie between 0 and 1 in "normal times." This literature also finds that spending multipliers tend to be larger than revenue multipliers. ${ }^{6}$ Based on a survey of 41 such studies, Mineshima and others (2014) show that first-year multipliers amount on average to 0.75 for government spending and 0.25 for government revenues in AEs. ${ }^{7}$ Assuming, in line with recent fiscal adjustment plans in AEs, that two thirds of the adjustment falls on expenditure measures, this would yield an overall "normal times" multiplier of about 0.6 .

However, these standard results have been challenged by the more recent literature. First, a number of studies have shown that multipliers can exceed 1 in "abnormal" circumstancesin particular when the economy is in a severe downturn or if the use and/or the transmission of monetary policy are impaired (see Section II.B). Second, some papers, which use a new "narrative" approach to identify exogenous fiscal shocks, find larger tax multipliers than conventional VAR models do. As shown in Tables 1 and 2, these narrative studies do not support the traditional view that spending multipliers are larger than revenue ones (Tables 1 and 2).

The narrative approach constitutes a methodological improvement upon the traditional measurement of fiscal shocks. The structural VAR methodology, which employs output elasticities of expenditure and revenue to filter out automatic stabilizers, may fail to capture exogenous policy changes correctly, because, for example, changes in revenues are not only due to output developments and discretionary policy, but also to asset and commodity price movements (IMF, 2010). The narrative approach instead seeks to identify exogenous fiscal shocks directly. On the tax side, the method uses estimates of fiscal measures extracted from

\footnotetext{
${ }^{6}$ This has often been explained with basic Keynesian theory, which argues that tax cuts are less potent than spending increases in stimulating the economy since households may save a significant portion of the additional after-tax income.

${ }^{7}$ The survey, based on linear VAR and DSGE models, excludes results from narrative approach studies. The list of 41 papers is provided in Mineshima and others (2014).
} 
budget documents (Romer and Romer, 2010), while excluding the subset of tax measures taken in response to short-term macroeconomic fluctuations (since these would not be exogenous). On the spending side, some studies have used news about future military spending as a measure of exogenous shocks (e.g., Ramey, 2011). The idea is that military spending is determined by wars and foreign policy developments and not by concerns about the state of the economy (Romer, 2011).

Table 1. Narrative Approach: First-Year Tax Multipliers ${ }^{1}$

\begin{tabular}{|c|c|c|c|}
\hline Study & Country & $\bar{T}$ & Notes \\
\hline Cloyne (2013) & United Kingdom & 0.6 & $\begin{array}{l}\text { Maximum multiplier reached after } 10 \text { quarters } \\
\text { (about 2.5) }\end{array}$ \\
\hline Favero and Giavazzi (2012) & United States & 0.7 & $\begin{array}{l}\text { Maximum multiplier reached after } 9 \text { quarters } \\
\text { (just below 1) }\end{array}$ \\
\hline Guajardo and others (2014) & Panel of OECD Countries & 1 & After two years, multiplier reaches about 3 . \\
\hline Hayo and Uhl (2014) & Germany & 1 & Maximum multiplier after 8 quarters (about 2.4). \\
\hline Mertens and Ravn (2013) & United States & 1 & $\begin{array}{l}\text { Maximum multiplier reached after } 8 \text { quarters } \\
\text { (about 2) }\end{array}$ \\
\hline Romer and Romer (2010) & United States & 1.2 & $\begin{array}{l}\text { Maximum multiplier reached after } 10 \text { quarters } \\
\text { (around 3) }\end{array}$ \\
\hline
\end{tabular}

${ }^{1}$ Response of output in percent following an exogenous tax shock of 1 percent of GDP.

Table 2. Narrative Approach: First-Year Spending Multipliers ${ }^{1}$

\begin{tabular}{|c|c|c|}
\hline Study & $\mathbf{G}$ & Notes \\
\hline Barro and Redlick (2011) & $0.4-0.6$ & $\begin{array}{l}\text { Based on U.S. defense spending news; 1917-2006; } \\
\text { Lower multiplier for temporary spending changes, } \\
\text { higher end of range for permanent spending } \\
\text { changes. }\end{array}$ \\
\hline Guajardo and others (2014) & 0.3 & $\begin{array}{l}\text { Overall spending shock. After two years, multiplier } \\
\text { reaches about } 1 .\end{array}$ \\
\hline Hall (2009) & 0.6 & Based on U.S. defense spending news; 1930-2008. \\
\hline $\begin{array}{l}\text { Owyang, Ramey, Zubairy } \\
\text { (2013) }\end{array}$ & $\begin{array}{l}\text { United States: } 0.8 \text {. } \\
\text { Canada: } 0.4-1.6\end{array}$ & $\begin{array}{l}\text { Based on U.S. defense spending news; 1890-2010 } \\
\text { for the United States, 1921-2011 for Canada. Two } \\
\text { year multipliers; in Canada range of multipliers } \\
\text { reflects low unemployment (low multiplier) and high } \\
\text { unemployment (high multiplier) regimes. In the United } \\
\text { States, multipliers do not differ significantly across } \\
\text { regimes. }\end{array}$ \\
\hline Ramey (2011) & $1.1-1.2$ & $\begin{array}{l}\text { Based on U.S. defense spending news; } 1939-2008 \\
\text { "defense-news" reflect changes in the expected } \\
\text { present value of government spending in response to } \\
\text { military events; peak multiplier after } 6 \text { quarters. }\end{array}$ \\
\hline
\end{tabular}

\footnotetext{
${ }^{1}$ Reported estimates correspond to the response of output in percent following an exogenous spending shock of
} 1 percent of GDP. First year multiplier unless otherwise noted. 


\section{Emerging Market Economies and Low-income Countries}

Little is known about the size of fiscal multipliers in EMEs and LICs. From a theoretical point of view, it is not clear whether multipliers should be expected to be higher or lower than in the AEs (Table 3).

\section{Table 3. Multipliers in EMEs and LICs}

\begin{tabular}{l|l}
\multicolumn{1}{c|}{$\begin{array}{c}\text { Factors increasing the multiplier in } \\
\text { EMEs and LICs }\end{array}$} & \multicolumn{1}{c}{$\begin{array}{c}\text { Factors decreasing the multiplier in } \\
\text { EMEs and LICs }\end{array}$} \\
\hline $\begin{array}{l}\text { Consumption smoothing behavior is less } \\
\text { prevalent when: (i) liquidity constraints arise } \\
\text { in less developed financial markets; and (ii) } \\
\begin{array}{l}\text { agents are less forward looking if there is } \\
\text { too much instability. }\end{array}\end{array}$ & $\begin{array}{l}\text { Precautionary saving may be larger in a } \\
\text { more uncertain environment. }\end{array}$ \\
\hline Monetary policy response is less effective. & $\begin{array}{l}\text { Inefficiencies in public expenditure } \\
\text { management and revenue administration. }\end{array}$ \\
\hline Automatic stabilizers are lower. & $\begin{array}{l}\text { Some LICs and EMEs may sustain lasting } \\
\text { positive output gaps due to supply } \\
\text { constraints. }\end{array}$ \\
\hline Government debt tends to be lower. & $\begin{array}{l}\text { With higher interest spreads, there is more } \\
\text { room for credibility and confidence effects. }\end{array}$ \\
\cline { 2 - 2 } & Economies are smaller and more open. \\
\hline
\end{tabular}

The scarce empirical literature available suggests that multipliers in EMEs and LICs are smaller than in AEs (Estevão and Samake, 2013; Ilzetzki and others, 2013; Ilzetzki, 2011; IMF, 2008; and Kraay, 2012). Some studies even conclude that multipliers are negative, particularly in the longer term (IMF, 2008) and when public debt is high (Ghosh and Rahman, 2008). Appendix 3 provides summary tables reporting estimates from studies on EMEs and LICs.

In terms of fiscal instrument, tax multipliers seem to be broadly similar to expenditure multipliers in EMEs. Ilzetzki (2011) finds that, in EMEs, spending multipliers range from 0.1 to 0.3 , while revenue multipliers lie between 0.2 and 0.4 in the short term. The fact that EME spending multipliers are, on average, lower than in AEs could be related to several factors, including expenditure inefficiencies, the difficulty to unwind expenditures (with increases more likely to become permanent), ${ }^{8}$ or composition effects. ${ }^{9}$

\footnotetext{
${ }^{8}$ Permanent consolidations are usually associated with lower multipliers (Barrell and others, 2012).

${ }^{9}$ According to Ilzetzki and others (2013), the low overall spending multiplier results from the combination of a government consumption multiplier of zero and a positive government investment multiplier of 0.6.
} 


\section{B. Determinants of the Size of Multipliers}

Two types of multipliers' determinants are identified in the literature: (i) structural country characteristics that influence the economy's response to fiscal shocks in "normal times;" and (ii) conjunctural/temporary factors (notably cyclical or policy-related phenomena) that make multipliers deviate from "normal" levels.

\section{Structural Characteristics}

Some structural characteristics influence the economy's response to fiscal shocks in "normal" times. ${ }^{10}$ Empirical estimates of fiscal multipliers vary accordingly, although the incremental effect of structural factors on multipliers is, to a large extent, unknown. Key structural characteristics include:

- Trade openness. Countries with a lower propensity to import (i.e., large countries and/or countries only partially open to trade) tend to have higher fiscal multipliers because the demand leakage through imports is less pronounced (Barrell and others, 2012; Ilzetzki and others, 2013; IMF, 2008).

- Labor market rigidity. Countries with more rigid labor markets (i.e., with stronger unions, and/or with stronger labor market regulation) have larger fiscal multipliers if such rigidity implies reduced wage flexibility, since rigid wages tend to amplify the response of output to demand shocks (Cole and Ohanian, 2004; Gorodnichenko and others, 2012).

- The size of automatic stabilizers. Larger automatic stabilizers reduce fiscal multipliers, since mechanically the automatic response of transfers and taxes offsets part of the initial fiscal shock, thus lowering its effect on GDP (Dolls and others, 2012).

- The exchange rate regime. Countries with flexible exchange rate regimes tend to have smaller multipliers, because exchange rate movements can offset the impact of discretionary fiscal policy on the economy (Born and others, 2013; Ilzetzki and others, 2013).

- The debt level. High-debt countries generally have lower multipliers, as fiscal consolidation (resp. stimulus) is likely to have positive (resp. negative) credibility and confidence effects on private demand and the interest rate risk premium (Ilzetzki and others, 2013, Kirchner and others, 2010).

\footnotetext{
${ }^{10}$ In the context of this paper, "structural" refers to characteristics that are intrinsic to the way the economy operates over longer time periods.
} 
- Public expenditure management and revenue administration. Multipliers are expected to be smaller when difficulties to collect taxes and expenditure inefficiencies limit the impact of fiscal policy on output. ${ }^{11}$

\section{Conjunctural Factors}

Conjunctural (temporary) factors tend to increase or decrease multipliers from their "normal" level. ${ }^{12}$ The recent literature has identified two main factors:

- The state of the business cycle. Fiscal multipliers are generally found to be larger in downturns than in expansions (Table 4). ${ }^{13}$ This is true both for fiscal consolidation and stimulus. A stimulus is less effective in an expansion, because, at full capacity, an increase in public demand crowds out private demand, leaving output unchanged (with higher prices). A consolidation is more costly in terms of output in a downturn, because credit-constrained agents cannot borrow to maintain (smooth) their consumption. Furthermore, Table 4 suggests that a downturn has a stronger effect on multipliers than an upturn. In other words, multipliers increase more in a recession than they decrease in an expansion. One reason could be that the supply constraint is asymmetric: while in a upturn the impact of fiscal policy is limited by the inelastic pool of resources (and eventually nullified when the economy reaches maximum productive and full employment capacity), this constraint does not exist when there is a slack in the economy, and the additional resources provided or extracted by the government have more direct traction on output.

- Degree of monetary accommodation to fiscal shocks. Expansionary monetary policy and a lowering of interest rates can cushion the impact of fiscal contraction on demand. By contrast, multipliers can potentially be larger, when the use and/or the transmission of monetary policy is impaired - as is the case at the zero interest lower bound (ZLB) (Erceg and Lindé, 2010; Woodford, 2011). Most of the literature focuses on the effect of temporary increases in government purchases and finds that the multiplier at the ZLB exceeds the "normal times" multiplier by a large margin (Table 5).$^{14}$ This effect is

\footnotetext{
${ }^{11}$ This argument implicitly assumes that fiscal multipliers measure the effect of planned fiscal measures on output (as in papers using a narrative approach), rather than the effect of actual changes in revenue or spending.

${ }^{12}$ By "conjunctural" we mean due to a series of temporary, non structural, circumstances.

${ }^{13}$ Jorda and Taylor (2013) examine how fiscal consolidation affects output distinguishing between slumps and upturns. Their measure of fiscal consolidation is based the narrative approach proposed by IMF (2010). They show that the cumulative impact of a 1 percent of GDP fiscal consolidation on real GDP is about -2.5 percent after four years in a slump compared to about 0.9 percent in a boom.

${ }^{14}$ Results on taxes are less conclusive. Eggertson (2010) investigates the impact of labor and capital tax cuts at the zero lower bound and finds that they have contractionary effects on output (negative multiplier), in contrast
}

(continued...) 
conditional on a number of factors. Erceg and Lindé (2010) show that the size of the shock matters at the ZLB: the larger the discretionary spending increases, the shorter the economy will stay at the ZLB, and therefore the lower the fiscal multiplier. Christiano and others (2011) find that implementation lags reduce the multiplier at the ZLB; for the multiplier to be significantly larger than in "normal times," it is critical that the ZLB is still present when the spending shock hits the economy.

The composition of fiscal adjustment could also be considered as a conjunctural factor affecting the size of the "overall" multiplier. However, Section II. A finds that recent empirical papers using a narrative approach challenge the common wisdom that short-term multipliers for government consumption and investment are higher than those on taxes.

Table 4. Fiscal Multipliers over the Business Cycle

\begin{tabular}{|c|c|c|c|c|c|c|}
\hline & \multicolumn{3}{|c|}{ Spending } & \multicolumn{3}{|c|}{ Revenue } \\
\hline & Expansion & Linear & Recession & Expansion & Linear & Recession \\
\hline $\begin{array}{l}\text { Auerbach and Gorodnichenko (2012a), } \\
\text { United States, } 6 \text { quarters }\end{array}$ & 0 & 0.4 & 1.7 & N/A & $\mathrm{N} / \mathrm{A}$ & $\mathrm{N} / \mathrm{A}$ \\
\hline $\begin{array}{l}\text { Auerbach and Gorodnichenko (2012b), } \\
\text { OECD, first year }\end{array}$ & -0.2 & 0.2 & 0.5 & $\mathrm{~N} / \mathrm{A}$ & $\mathrm{N} / \mathrm{A}$ & $\mathrm{N} / \mathrm{A}$ \\
\hline $\begin{array}{l}\text { Auerbach and Gorodnichenko (2014), } \\
\text { Japan, } 4 \text { quarters }{ }^{a}\end{array}$ & 1 & 1.2 & 2.4 & $\mathrm{~N} / \mathrm{A}$ & $\mathrm{N} / \mathrm{A}$ & $\mathrm{N} / \mathrm{A}$ \\
\hline Batini and others (2012), 4 quarters $^{\mathrm{b}}$ & 0.82 & 0.93 & 2.08 & -0.08 & -0.17 & 0.08 \\
\hline Baum and others (2012), 4 quarters ${ }^{c}$ & 0.72 & 0.79 & 1.22 & -0.04 & 0.29 & 0.35 \\
\hline $\begin{array}{l}\text { Canzoneri and others, 2012, DSGE, } \\
\text { United States, impact multiplier }\end{array}$ & 0.89 & 1.3 & 2.25 & N/A & $\mathrm{N} / \mathrm{A}$ & $\mathrm{N} / \mathrm{A}$ \\
\hline $\begin{array}{l}\text { Hernandez de Cos and Moral-Benito } \\
\text { (2013), Spain, } 4 \text { quarters }{ }^{d}\end{array}$ & 0.6 & 0.65 & 1.3 & N/A & $\mathrm{N} / \mathrm{A}$ & $\mathrm{N} / \mathrm{A}$ \\
\hline $\begin{array}{l}\text { Owyang, Ramey, Zubairy (2013), } \\
\text { United States, } 2 \text { year multipliers }\end{array}$ & 0.7 & $\mathrm{~N} / \mathrm{A}$ & 0.8 & $\mathrm{~N} / \mathrm{A}$ & $\mathrm{N} / \mathrm{A}$ & $\mathrm{N} / \mathrm{A}$ \\
\hline $\begin{array}{l}\text { Owyang, Ramey, Zubairy (2013), } \\
\text { Canada, } 2 \text { year multipliers }\end{array}$ & 0.4 & $\mathrm{~N} / \mathrm{A}$ & 1.6 & N/A & $\mathrm{N} / \mathrm{A}$ & $\mathrm{N} / \mathrm{A}$ \\
\hline
\end{tabular}

a Using deviation of output from HP trend as measure of business cycle.

${ }^{b}$ Average of all countries in sample (including euro area).

${ }^{\mathrm{c}}$ Average of $\mathrm{G} 6$ in sample.

${ }^{\mathrm{d} U s i n g ~ o u t p u t ~ g a p ~ t o ~ d e f i n e ~ e x p a n s i o n s ~ a n d ~ r e c e s s i o n s . ~}$

${ }^{\mathrm{e}}$ Regimes reflect high and low employment.

to normal times when they are expansionary. He argues that this is due to their deflationary effects, which, at the $\mathrm{ZLB}$, raise real interest rates. 
Table 5. Government Spending Multipliers and the Zero Lower Bound

\begin{tabular}{|c|c|c|c|}
\hline & No ZLB & ZLB & Notes \\
\hline $\begin{array}{l}\text { Christiano and } \\
\text { others (2011) }\end{array}$ & 1.1 & 3.7 & $\begin{array}{l}\text { Impact multiplier for temporary increase in spending in the } \\
\text { United States. Multiplier at ZLB assumes policy implemented } \\
\text { at time t when ZLB begins to bind. If there are implementation } \\
\text { lags of fiscal stimulus, multiplier declines. For instance, an } \\
\text { implementation lag of } 1 \text { period reduces the multiplier to } 1.5 \text {. }\end{array}$ \\
\hline $\begin{array}{l}\text { Eggertson } \\
(2010)\end{array}$ & 0.5 & 2.3 & $\begin{array}{l}\text { Impact multiplier for temporary increase in government } \\
\text { spending in the United States. }\end{array}$ \\
\hline $\begin{array}{l}\text { Erceg and } \\
\text { Linde (2010) }\end{array}$ & 1 & 4 & $\begin{array}{l}\text { ZLB multiplier of } 4 \text { is based on a temporary spending } \\
\text { increase of } 1 \text { percent of GDP in the United States, and ZLB } \\
\text { duration of } 8 \text { quarters. Larger positive spending shocks are } \\
\text { associated with lower multipliers since they shorten the } \\
\text { duration at which the economy is at ZLB. For instance, for a } \\
\text { government spending increase of above } 3.5 \text { percent of GDP, } \\
\text { the multiplier declines to } 1.5 \text {. Similarly, a cut in spending } \\
\text { increases the multiplier since it prolongs the duration of ZLB. } \\
\text { For instance, a cut of } 1 \text { percent of GDP is associated with a } \\
\text { multiplier of up to } 6 \text {. }\end{array}$ \\
\hline
\end{tabular}

\section{Persistence of Fiscal Multipliers}

Understanding the shape and persistence of fiscal multipliers is crucial to compute the effects of fiscal policy on output beyond the first year. The persistence of multipliers should be distinguished, conceptually and empirically, from the persistence of the fiscal shock (which depends on whether the fiscal measure is temporary or permanent). In general, model-based and econometric studies find that the output effect of an exogenous fiscal shock vanishes within five years - even if fiscal measures are permanent. The effect does not decline in a linear way but usually has an inverted $U$ shape, with the maximum impact occurring in the second year (Batini and others, 2012; Baum and others, 2012; Coenen and others, 2012). Based on the literature review by Mineshima and others (2014), the second-year multiplier is, on average, $10-30$ percent higher than in the first-year.

However, the duration of these effects varies depending on several factors examined in the following paragraphs: (i) the persistence of the fiscal shock; (ii) the type of fiscal instrument; and (iii) conjunctural factors such as the cyclical position and whether monetary policy responds to the fiscal shock.

Permanent fiscal measures tend to have more persistent output effects than temporary ones. DSGE models clearly differentiate between temporary and permanent fiscal measures. ${ }^{15} \mathrm{In}$

\footnotetext{
${ }^{15}$ In vector autoregression analysis, on the other hand, the distinction between temporary and permanent fiscal measures is not clear-cut. Although impulse response functions are based on one-off (temporary) shocks, these shocks propagate in the system's dynamic equations, which are estimated and, therefore, reflect the persistence of past shocks.
} 
these models, the effect of the temporary fiscal measure does not generally last beyond the duration of the shock itself, because forward-looking agents are not affected by temporary changes in their disposable income, while credit-constrained ones are only affected over the duration of the shock. For instance, Coenen and others (2012) show that GDP returns to its baseline level after two years in the case of a two-year temporary increase in government consumption. By contrast, the effect of a permanent fiscal shock may be more persistent, although it generally does not last more than five years (partly because of the endogenous response of prices and monetary policy).

The persistence of the effect of discretionary fiscal policy on output may to some extent depend on the fiscal instruments used. The model-based literature shows that a permanent discretionary change in indirect taxes, government consumption, and transfers ${ }^{16}$ has only short-term output effects, typically vanishing within five years (Anderson and others, 2013; Coenen and others, 2012; European Commission, 2010). In contrast, the effect of a permanent discretionary change in public investment or corporate taxes is longer, and may even be permanent, with multipliers steadily increasing after the first year towards their longterm values (Coenen and others, 2012). This is because corporate income taxes have distortionary effects on investment, leading to a long-run decrease in the capital stock, and hence the productive capacity of the economy. Similarly, cuts in government investment in infrastructure could reduce the productivity of the economy and therefore have durable negative effects on output.

The business cycle also affects the persistence and shape of fiscal multipliers. Fiscal shocks occurring in recessions or when production is below potential may have more persistent effects, because of hysteresis effects (Delong and Summers, 2012; IMF, 2011) or because credit constrained agents cannot offset the reduction in their disposable income by borrowing. The shape of multipliers also depends on the cyclical position: Auerbach and Gorodnichenko (2013) show that multipliers steadily increase if the initial spending shock occurs in a recession, while they steadily decline if the shock happens in an expansion.

Finally, monetary policy is an important determinant of persistence. Persistence is higher if monetary policy does not offset fiscal shocks (i.e., by raising interest rates in response to a fiscal stimulus, or expanding the money supply in response to fiscal tightening). DSGE models show that even if the fiscal shock is temporary, a public consumption-based stimulus lasting for two years can have a positive effect on output of up to five years if there is no response of monetary policy (Coenen and others, 2012). In contrast, if monetary policy offsets the fiscal shock, its effect will not last beyond the duration of the fiscal stimulus.

\footnotetext{
${ }^{16}$ As well as labor income taxes in some models.
} 


\section{THE BUCKeT APPROACH}

For countries where fiscal multipliers are not readily available, general findings from the literature on other countries can be used. Specifically, the bucket approach bunches countries into three groups that are likely to have similar multiplier values based on their structural characteristics.

The choice of the characteristics and the calculation of their marginal effect on multipliers are mostly based on findings from studies on advanced countries. Our simple method hypothesizes that similar factors affect multipliers in EMEs and LICs where empirical and model-based estimates are not widely available and often of poor quality.

\section{A. Main Steps}

The selection of first-year overall fiscal multipliers can be conducted in three steps.

First, assign scores to the country based on how many structural characteristics associated with "large" multipliers it possesses. The definition of the characteristics and the thresholds are identical across countries except the "safe" level of public debt, which is assumed to be lower in EMEs/LICs in light of the empirical evidence that AEs can sustain higher debt without jeopardizing market access. Specifically, assign a value of one for each of the following characteristics if the characteristic is present:

Low trade openness. The economy is relatively closed, with a ratio of imports to domestic demand below 30 percent on average over the past five years. ${ }^{17}$

- High labor market rigidities. The country has strong labor unions and/or its labor market is strongly regulated (indicatively, "strong" means that labor market rigidity measures 0.8-1 in indices of labor market rigidity ranging from 0 -weak to 1 -strong - as in Botero and others, 2004).

- Small automatic stabilizers. Automatic stabilizers measured by the ratio of public spending to nominal GDP are "small" (for instance, when the ratio is below 0.40). ${ }^{18}$

\footnotetext{
${ }^{17}$ This corresponds to the weighted-average value across AEs, EMEs, and LICs between 2008 and 2013. Alternative measures of openness could be used, including the more conventional ratio of exports plus imports to GDP.

${ }^{18}$ This threshold corresponds to the weighted-average across AEs, EMEs, and LICs between 2008 and 2013. See Baunsgaard and Symansky (2009) and Fedelino and others (2009) for alternative measures of the size of automatic stabilizers.
} 
- Fixed or quasi-fixed exchange rate regime. The exchange rate arrangement of the country is not fully flexible. Countries that have the following exchange rate arrangements in the Annual Report on Exchange Arrangements and Exchange Restrictions (AREAER) could be assigned a score of one: no specific legal tender; currency board; conventional peg; stabilized arrangement; crawling peg; and crawl-like arrangement. Countries within a single currency area would, in general, receive a score of 1 (unless the fiscal shock happens in all countries simultaneously, which would most likely trigger a common exchange rate response).

- Low/safe public debt level. The country's gross government debt is below a level that is generally considered "safe" by financial markets (i.e., with a relatively low risk premium). For AEs, this level may be assumed to be 100 percent of GDP, while a threshold of 40 percent can be used for EMEs. ${ }^{19}$ These thresholds are only indicative. In some cases, the debt ratio does not provide an adequate benchmark for the soundness of public finances, and it should be complemented with other indicators of fiscal space, such as the fiscal balance, the share of debt held by residents, or the status of public bonds as safe haven investment in international currency countries.

- Effective public expenditure management and revenue administration. On the spending side, the assessment could rely on the Public Expenditure and Financial Accountability (PEFA) performance measurement framework. On the revenue side, calculations of tax productivity (measured by the ratio of actual to potential tax receipts) could provide a first evaluation.

\section{Second, sum the scores to determine the likely level of the first-year multiplier (low, medium, or high) in "normal" times.}

Given the limited empirical evidence on the relative importance of the factors determining the level of the multiplier, all structural characteristics receive an equal weight. ${ }^{20}$ Countries with total scores of 0 to 3 may be assumed to have "low" multipliers; countries with total scores of 3 or 4 have "medium" multipliers; and countries with total scores of 4 to 6 end up in the "large" multiplier category. Because of the overlap, countries with totals of 3 or 4 may

\footnotetext{
${ }^{19}$ Ardagna and others (2007) and Conway and Orr (2002) show that sovereign borrowing costs are much more sensitive to further changes in the debt-to-GDP ratio when public debt is above 100 percent of GDP in advanced economies. Belhocine and Dell'Erba (2013) find that the sensitivity of spreads to debt sustainability doubles as public debt increases above 45 percent of GDP in EMEs.

${ }^{20}$ Auerbach and Gorodnichenko (2013) is one of a few empirical studies that analyze the relative importance of the structural characteristics. The authors find that labor market rigidities and the level of government debt are relatively more important than openness. Corsetti and others (2012) study how the effect of government spending varies with the economic environment in OECD countries. There are also a number of model-based papers that examine the relative weight of different factors (e.g., Barrell and others, 2012).
} 
end up in multiple categories; this flexibility allows using judgment to take into account country-specific factors and extreme values of structural characteristics.

Table 6 shows a possible distribution of first-year multipliers for each category. Each country group is assigned a multiplier range, rather than a point value, to account for differences among countries in the same grouping, and to allow for judgment when selecting multipliers. The range of medium multipliers (0.4-0.6) is that found in Mineshima and others (2014) for AEs, assuming that the fiscal shock (stimulus or tightening) is equally distributed between spending and revenue measures and that the cyclical conditions are "normal" (the output gap is close to zero and monetary policy is unconstrained). The three buckets are also consistent with the distribution of OECD model-based multipliers, which are found to be roughly equally-distributed into the three categories. Simple theoretical considerations provide further support to the overall range $(0.1-1.0) .{ }^{21}$ Finally, the recent papers using a narrative approach also find first-year multipliers within this range (see Section II.A).

\section{Table 6. Ranges of First-Year Overall Multipliers}

(Normal Times)

\begin{tabular}{cc}
\hline Country Category & Multiplier Ranges \\
\hline Low multiplier & $0.1-0.3$ \\
Medium multiplier & $0.4-0.6$ \\
High multiplier & $0.7-1.0$ \\
\hline
\end{tabular}

Third, scale up or down the range assigned through the scoring method depending on whether the country is undergoing any of the conditions described in the list of "conjunctural" characteristics. More precisely:

- Adjust the range for the cycle. If the economy is at the lowest point of the cycle (maximum negative output gap based on historical patterns), ${ }^{22}$ increase both the lower and upper bound of the multipliers range by 60 percent. If on the other hand, the economy is at a peak (maximum positive output gap), decrease both bounds by 40 percent. Scaling up the range this way accounts for empirical findings discussed in Section II.B, including the asymmetry of cyclical effects. When the output gap is zero, no adjustment should be made. For all other cases, interpolate.

\footnotetext{
${ }^{21}$ A minimum multiplier of 0 corresponds to the case of perfect Ricardian equivalence (Table 6 sets a floor of 0.1 , since 0 would make the scaling exercise in Step 3 irrelevant). A maximum multiplier of 1 is consistent with: (i) the pure accounting effect of public expenditure on output; and (ii) a simple calculation of the closedeconomy Keynesian multiplier for a fiscal shock equally divided between spending and revenue measures and an estimated short-term propensity to consume of 0.33 (based on U.S. estimates from Mehra, 2001).

${ }^{22}$ It is obviously difficult to determine ex ante whether the economy has reached a cyclical trough or peak. An analysis of the amplitude and duration of past cycles may guide this assessment.
} 
- Adjust the range for the monetary policy stance. If monetary policy is at the effective lower bound and is fully constrained, increase both bounds of the multiplier range by 30 percent. ${ }^{23}$ If the monetary policy is constrained by other considerations, interpolate between 0 and 30 percent.

As discussed above, we do not introduce adjustments for the fiscal package composition, as recent papers show that spending multipliers are not necessarily higher than revenue multipliers.

We propose to use a multiplicative formula to account for the combined effect of conjunctural characteristics on the multiplier size. A multiplicative formula implies that these characteristics interact with each other and have cumulative effects. For instance, based on the above calibrations and the formula, the marginal effect of the cycle is stronger if a country is at the ZLB. ${ }^{24}$

Specifically, adjust the upper and lower bounds of the multiplier range as follows:

$$
M=M_{N T} *(1+C y c l e) *(1+\text { Mon })
$$

Where $M$ is the final multiplier estimate, $\mathrm{M}_{N T}$ is the "normal times" multiplier derived from step 2, Cycle is the cyclical factor ranging from -0.4 to +0.6 , and Mon is the monetary policy stance factor ranging from 0 to 0.3 .

As stressed above, the adjustment factors should be interpolated when the conjunctural characteristics are moderate. For example, if the economic cycle is only slightly below potential, the Cycle adjustment factor should be set to a positive but small number, using a full adjustment of 0.6 only when the slack in the economy is substantive.

With the scaling factors, under various combination scenarios, first-year multipliers may vary from about 0 to 2. A first-year multiplier of around 2 may seem elevated. However, such an estimate is not uncommon in the literature taking into account the ZLB or the state of the economy.

Although the calibration of the "bucket approach" is based on AE studies, the methodology can be applied to EMEs and LICs. These countries would generally be placed in the low-

\footnotetext{
${ }^{23}$ In the model-based literature, the effect of the ZLB on the multiplier size is usually larger than assumed here (Table 5). However this literature does not account for the fact that multipliers are also larger during downturns. Since monetary policy usually hits its effective low when the economy is in a downturn, having a larger scaling factor would lead to double counting.

${ }^{24}$ Alternatively, an additive formula could be used in the conjunctural factors are assumed to be independent: $M=M_{N T} *(1+$ Cycle + Mon $)$.
} 
multiplier bucket reflecting their structural characteristics (trade openness, flexible labor markets, spending and revenue inefficiencies, and, in some cases, unsafe debt levels). The $0.1-0.3$ range of estimates in the low-multiplier category is consistent with the empirical findings of Ilzetzki (2011) for EMEs.

\section{B. Illustration}

For illustrative purposes, this section computes a range of first-year multipliers for the United States using the bucket approach. We assume that the United States has a negative output gap. Tables 7 and 8 describe how the first-year overall multiplier is derived. Although the U.S. public debt is above 100 percent of GDP, we classify its debt as "safe" in light its role as safe haven asset for international investors.

The total score of 4 leaves room for discretion in the choice of the bucket (medium or high). Based on existing empirical estimates and prior knowledge, we assign the United States to the high bucket. The upper and lower ranges are adjusted by the following factors: +0.3 (moderate negative output gap) and +0.1 (constrained monetary policy).

The results from the bucket approach seem reasonable. By comparison, Auerbach and Gorodnichenko (2012a) estimate a first year expenditure multiplier of about 1.4 in recessions, while Baum and others (2012) find an overall downturn multiplier of 0.9 (under the assumption that half of the adjustment falls on spending), and Batini and others (2012) find a multiplier of 1.2 with the same assumption.

\begin{tabular}{lc} 
Table 7. Scoring Based on Structural & Characteristic \\
\hline Structural Characteristic (non-zero if applies) & United States \\
\hline & \\
Relatively Closed & 1 \\
Rigid Labor Markets & 0 \\
Small Automatic Stabilizers & 1 \\
Fixed Exchange Rate Regime & 0 \\
Safe Government Debt & 1 \\
Effective expenditure/revenue management & 1 \\
Total score & 4 \\
\hline
\end{tabular}

Table 8. Derivation of First-year Multiplier Using the Bucket Approach

\begin{tabular}{cccc}
\hline & Score & Multiplier Range & Multiplier after scaling up/down \\
\hline United States & 4 & Medium (0.4-0.6) & $0.6-0.9$ \\
United States & 4 & $\underline{\text { High }(0.7-1)}$ & $\underline{1.0-1.4}$ \\
\hline
\end{tabular}

\section{Caveats and Extensions}

The "bucket approach" only provides rule-of-thumb guidance on the size of fiscal multipliers and should not be applied in a mechanical way. Although fiscal multipliers in EMEs and 
LICs are likely to be affected by similar factors as in AEs, it is important to keep in mind that the bucket approach was calibrated with studies based on the latter group of countries. In all cases, judgment should be exercised based on priors and economic theory to modify multipliers appropriately. Examples where further adjustment to the multiplier level could be justified include:

- When a great proportion of the economy is controlled by the government and the private sector is accordingly small (there is limited scope for crowding-out effect of private demand), the multiplier could be adjusted upwards.

- In economies with de jure flexible exchange rate regimes, but where monetary policy is constrained by financial stability considerations due to currency mismatches, the multiplier could also be adjusted upwards.

- In cases where fiscal adjustment is highly credible, the multiplier could be adjusted downwards. It has been argued that confidence effects can alleviate the costs of fiscal consolidation.

Finally, the bucket approach suggests a range of first-year multiplier estimates. To determine the effect of fiscal shocks in subsequent years, the literature on persistence provides some (limited) guidance. Based on these findings reviewed in Section II.C, it seems safe to assume a decline to zero in multiplier size over five years, with possibly a higher multiplier in the second year (by 10 to 30 percent relative to the first-year).

\section{Conclusions}

Fiscal multipliers are key inputs for the assessment of the short-term macroeconomic impact of fiscal policy. Their use in operational work is still heterogeneous, despite recognized benefits. They make macroeconomic projections more transparent, reduce forecasting errors, and ensure that projections rely on specific and consistent assumptions. They also help better track economists' thinking over time.

This paper offers two main contributions. First, it provides an overview of the literature, starting with the size of short-term multipliers, followed by a discussion on their main determinants. These include structural factors, such as trade openness and the exchange rate regime, as well as temporary factors, such as the state of the business cycle. Conjunctural factors can make multipliers deviate quite significantly from their "normal" or "average" level. To our knowledge, this paper is also the first one to take stock of the growing literature on multipliers in EMEs and LICs. Multipliers are found to be lower in these countries, likely due to difficulties to collect taxes and expenditure inefficiencies, which limit the impact of fiscal policy on output. The paper also reports some findings on the persistence of multipliers. The effect of discretionary fiscal policy on output typically vanishes within five 
years. The multiplier does not decline in a linear way but has an inverted $U$ shape, with the maximum impact usually occurring in the second year.

Second, the paper offers some practical guidance on how to select fiscal multipliers in countries where estimates are not available from the literature and constraints on data availability limit the scope for further research. The proposed approach identifies ranges of multipliers based on countries' characteristics and environmental factors. This method is indicative, and should be considered as a starting point for quantifying the impact of fiscal shocks on activity. A proper choice of fiscal multipliers requires judgment based on a broader range of considerations, including data definitions, the importance of off-budget items, the monetary regime and the state of the financial sector. 


\section{APPENDiX I. MULTIPLIER EsTiMATION TECHNIQUES IN THE LiteRATURE}

Broadly speaking, the literature relies on two main methods to derive fiscal multipliers: empirical estimation and model-based approaches. Both techniques typically report separate multipliers for revenue and expenditure measures. The empirical literature focuses mostly on the advanced G20 economies, with the largest number of studies available for the United States. Model-based fiscal multipliers from DSGEs are available for more countries. For example, the OECD regularly publishes reports that provide model-based estimates of multipliers for their membership (Barrell and others, 2012; OECD, 2009). In most studies, sector coverage is the general government.

Both methods have benefits and limitations (Box A.1.1). Empirical methods are often based on the econometric estimation of SVAR models. Their main advantage is that they use country-specific data to explore the relationship between fiscal policy and output. However, the SVAR methodology presents some limitations in the measurement of structural shocks and has been criticized. Model-based approaches, on the other hand, are based on current characteristics of the economy and describe the economic system as a whole by analyzing the interaction of many microeconomic decisions. However, multipliers coming out of DSGEs tend to be quite sensitive to the models' characteristics.

\section{Box A.1.1. Pros and Cons of Empirical Versus Model-Based Estimates}

Empirical Estimations. Vector autoregressive (VAR) models are widely used to estimate the size of fiscal multipliers. This method is justified on the grounds that the variables of interest (revenue, spending, output, interest rate and inflation) are interrelated and there are multiple causal relationships. When estimating a VAR, the key challenge is to isolate exogenous fiscal shocks. Since the seminal paper by Blanchard and Perotti (2002), a common approach has been to use a structural identification method (also called SVAR). This method uses various identifying assumptions to extract structural shocks and estimate their impact on GDP.

SVAR models are subject to some shortcomings. First, the structural identification approach may fail to capture purely exogenous fiscal shocks, because, for example, it does not filter out asset and commodity price movements (IMF, 2010). To address this issue, recent studies have developed a "narrative" or "action-based" approach, using direct estimates of fiscal measures from government documents (e.g., budget documents) to identify exogenous fiscal shocks. There are also some attempts to combine the narrative approach and SVARs by including tax shocks derived from budget documents into the SVAR framework (Favero and Giavazzi, 2012; and Mertens and Ravn, 2012). Second, SVARs (as well as simple VARs) provide an estimate of the average response of output to exogenous fiscal shocks based on past information. If the country under study has undergone major structural changes, the "average" multiplier will not measure accurately the effect of fiscal policy on output today. Third, SVARs are generally linear and do not capture the important feature that multipliers are state-contingent. A few recent studies have addressed this issue by employing non-linear SVARs to examine whether multipliers vary across the business cycle (Auerbach and Gorodnichenko, 2012a and 2012b; Batini and others, 2012; Baum and others, 2012).

Model-based estimations. New Keynesian macroeconomic models, particularly DSGE models, are commonly used for simulating the impact of fiscal policy on growth (Coenen and others (2012) review fiscal multipliers generated in seven DSGE models). One advantage of DSGE models is that they describe the behavior of the economy as a whole by analyzing the interaction and combination of many microeconomic decisions. This is in contrast to vector autoregressive models, which look at the interactions of only a few variables.

Continued 


\section{Box A1.1. Pros and Cons of Empirical Versus Model-Based Estimates}

Concluded

However, analyzing fiscal multipliers with DSGE models also presents challenges. First, there is little consensus about fiscal policy modeling. For example, unlike the Taylor rule for monetary policy, there is no generally accepted fiscal rule to be included in a DSGE. Second, many DSGE models are based on linearized equations, thereby ruling out state-dependent multipliers. Third, results of simulations tend to be sensitive to the choice of certain parameters (e.g., degree of price and wage rigidities, habit persistence, investment adjustment cost, and proportion of liquidity-constrained agents). Fourth, multipliers coming out of DSGEs depend, to some extent, on the specific modeling assumptions, especially if the models are calibrated rather than estimated. When the same model is used to measure multipliers in different countries, the results tend to show less dispersion than when multipliers are estimated by empirical studies.

Choosing between alternative multiplier estimates requires assessing whether macroeconomic conditions faced by the country are "normal" by historical standards. In countries where several estimates are available, the following rule of thumb could be used: empirical studies, which usually rely on long-period estimations, are most useful to estimate multipliers under "average" or "normal" circumstances (small output gap, interest rates not constrained by the zero lower bound...), with narrative approaches generally considered as providing higher-quality estimates. If today's circumstances differ significantly from those prevailing during the estimation period of the empirical study, model-based multipliers may be more useful, as they can reflect unusual conditions (such as a high proportion of creditconstrained agents) or conditions with few historical precedents (such as a zero lower bound on interest rates).

It is important to note that the narrative approach also presents some practical difficulties:

- Fiscal measures are assessed against a benchmark of "unchanged policy," which is not always clearly defined. A no-policy change scenario describes what would have happened in the absence of government interventions, but there is room for interpretation. For instance, freezing government wages is usually considered as a tightening policy but it may be considered expansionary if the assumption is that wages normally adjust to inflation and the country is experiencing a deflation period or productivity is declining.

- If measures are announced for the future and then reversed, two or zero measures can be registered - depending on whether the initial measure is included in the new baseline.

- The methodology used to quantify the effect of measures is not transparent and may be incorrect. Methodology may differ across countries and be influenced by data availability, as well as political decisions. Moreover, the quantification may be based on wrong macro assumptions. The yield of administrative measures is particularly difficult to assess.

- There may also be conflicting evidence from various official sources, which would necessitate building a "consensus estimate" of the size of fiscal shocks. 


\section{ApPendix II. Fiscal Multipliers by InSTRUment AND CONFIDENCE EFFECT}

While there is some agreement in the literature about the determinants of multipliers, there is less consensus about the size of short-term multipliers across different fiscal instruments. The discussion below summarizes some of the ongoing debate.

\section{A. Are Multipliers Different Across Fiscal Instruments?}

Macroeconomic models imply a clear hierarchy of fiscal instruments (Coenen and others, 2012; European Commission, 2010). On the spending side, investment has the highest shortterm multiplier, followed by government wages and government purchases, while untargeted transfers to households are associated with the lowest output impact among spending instruments. On the revenue side, the ranking of tax instruments reflects their perceived distortionary effects. Corporate income taxes and personal income taxes have the most negative effects on GDP. Consumption taxes do relatively better (Figure A.2.1). ${ }^{25}$

Figure A.2.1. Average of DSGE Models: First-year Multipliers

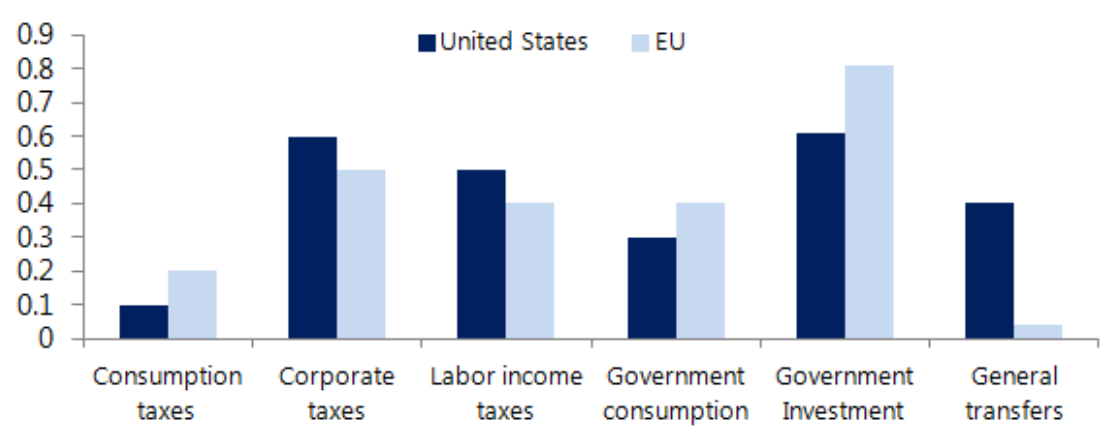

Note: Permanent measures, average of 7 DSGE models (Coenen and others, 2012). For the United States: average of DSGE models from Bank of Canada, EC, ECB and GIMF. For EU: average of DSGE models from EC, ECB and GIMF.

Empirically, it is more difficult to identify robust differences between instruments, but the few available studies point to a ranking of instruments quite different from the standard hierarchy. They suggest that labor income taxes are associated with larger multipliers than corporate income taxes (Table A.2.1); and that increases in consumption taxes are associated with sizeable short-term output losses. There is also no clear evidence that government investment is associated with larger multipliers than government consumption in AEs (Perotti, 2004). In emerging economies, some empirical studies (Ilzetzki and others, 2013) find that government investment is associated with positive multipliers, while discretionary changes in government consumption do not have any significant effects on output.

\footnotetext{
${ }^{25}$ Property taxes seem to be the most growth-friendly instrument (OECD 2009; OECD 2010; and EC 2010).
} 
Table A.2.1 Empirical Studies: Short-run Multipliers by Instrument

\begin{tabular}{|c|c|c|c|c|c|c|c|}
\hline Country & Study & PIT & CIT & VAT & GC & GI & Details \\
\hline \multirow[t]{2}{*}{ USA } & \multirow{2}{*}{$\begin{array}{l}\text { Mertens and Ravn } \\
\quad(2013)^{1}\end{array}$} & 1.4 & 0.4 & & & & Impact \\
\hline & & 1.8 & 0.6 & & & & 3-4 quarters \\
\hline \multirow{2}{*}{$\begin{array}{l}\text { Panel of } 14 \\
\text { industrial } \\
\text { countries }\end{array}$} & \multirow{2}{*}{$\begin{array}{l}\text { Riera-Chrichton and } \\
\text { others }(2012)^{2}\end{array}$} & & & 1 & & & Impact \\
\hline & & & & 2.7 & & & 3 quarters \\
\hline USA & \multirow[t]{5}{*}{ Perotti $(2004)^{3}$} & & & & 1.4 & 1.2 & 4 quarters \\
\hline DEU & & & & & 0.8 & 5 & 4 quarters \\
\hline GBR & & & & & 0.6 & 0 & 4 quarters \\
\hline CAN & & & & & 0.6 & 0.4 & 4 quarters \\
\hline AUS & & & & & 0.6 & -0.3 & 4 quarters \\
\hline Advanced & \multirow{2}{*}{$\begin{array}{l}\text { Ilzetzki and others } \\
(2013)^{4}\end{array}$} & & & & 0.4 & 0.4 & Impact \\
\hline Developing & & & & & 0 & 0.6 & Impact \\
\hline
\end{tabular}

${ }^{1}$ Narrative dataset on tax shocks, 1950-2006, SVAR estimation, quarterly data. Impact of 1 percentage point cut in average tax rate on real GDP per capita.

${ }^{2} 14$ industrial countries, 1980-2009; quarterly database on value-added tax rate changes. Effect of one unit shock decrease in VAT revenue collection on output.

${ }^{3}$ SVAR, quarterly data, 1960-2001 (West Germany up to 1989). Effect of $\$ 1$ increase in spending on real GDP level.

${ }^{4}$ SVAR; panel; quarterly data; unbalanced panel of 44 countries (20 high income, 24 developing); and coverage spans from as early as 1960 to 2007 . Effect of $\$ 1$ increase in spending on the real GDP level.

Note: PIT=personal income taxes; CIT= corporate income taxes; $\mathrm{GC}=$ government consumption; and $\mathrm{Gl}=$ government investment.

\section{B. Can Fiscal Consolidations Be Expansionary?}

Before and early on in the crisis, a number of researchers and policymakers argued that positive confidence effects could dominate the adverse mechanical effects of fiscal consolidation, leading to "expansionary fiscal consolidations." The literature on "expansionary fiscal contractions" suggests, in particular, that expenditure-based fiscal adjustments can be expansionary, even in the short term (Giavazzi and Pagano, 1990; Alesina and Perotti, 1996; and Alesina and Ardagna, 1998, 2010). This is consistent with the assumption that expenditure-based consolidation increases confidence, resulting in lower interest rates and a boost in private sector demand.

However, recent research suggests that previous findings of such expansionary effects are sensitive to how fiscal consolidation is defined (Jordà and Taylor, 2013, and Guajardo and others, 2014), and that the most famous episodes of expansionary contractions observed in Europe in the 1980s and 1990s were typically driven by external demand more than by a surge in internal private demand on the back of confidence effects (Perotti, 2012). While more evidence needs to be gathered, it does not appear that confidence effects have played a major role in the Great Recession and its aftermath. 


\section{APPENDIX III. SHORT-TERM MULTIPLIERS IN EMES AND LICS}

Tables A.3.1 and A.3.2 report multiplier estimates from studies on EMEs and LICs. Similar tables are available in Mineshima and others (2014) for AEs.

Table A.3.1. Empirical Studies: Short-Term Multipliers in EMEs/LICs

\begin{tabular}{|c|c|c|c|c|}
\hline Country & Study & $\mathbf{G}$ & $\mathbf{T}$ & Notes \\
\hline Argentina & Anós-Casero and others (2010) & 0 & 0 & \\
\hline Bulgaria & Muir and Weber (2013) & 0.2 & 0.4 & \\
\hline China & Wang and Wen (2013) & $1.7 / 2.8$ & $N / A$ & Consumption multiplier \\
\hline Costa Rica & Estevão and Samake (2013) & 0.2 & 0 & \\
\hline Croatia & $\begin{array}{l}\text { Simovic and Deskar-Škrbić } \\
(2013)\end{array}$ & 0.8 & 0.6 & Central government data \\
\hline $\begin{array}{l}\text { Dominican } \\
\text { Republic }\end{array}$ & Estevão and Samake (2013) & 0.1 & 0 & \\
\hline El Salvador & Estevão and Samake (2013) & 0.2 & 0 & \\
\hline Guatemala & Estevão and Samake (2013) & 0.3 & 0 & \\
\hline Honduras & Estevão and Samake (2013) & 0.3 & 0 & \\
\hline Indonesia & Tang and others (2010) & -0.3 & 0.4 & $\begin{array}{l}\text { Average of different VAR } \\
\text { specifications }\end{array}$ \\
\hline Malaysia & Tang and others (2010) & 0.2 & 0.4 & $\begin{array}{l}\text { Average of different VAR } \\
\text { specifications }\end{array}$ \\
\hline Malaysia & Rafiq and Zeufack (2012)* & $2.7 / 2$ & $0.1 / 0.2$ & $\begin{array}{l}\text { Peak multiplier; } \\
\text { downturn/upturn }\end{array}$ \\
\hline Nicaragua & Estevão and Samake (2013) & 0.1 & 0 & \\
\hline Panama & Estevão and Samake (2013) & 0.5 & 0 & \\
\hline Peru & Anós-Casero and others (2010) & 0 & 0 & \\
\hline Philippines & Tang and others (2010) & 0.4 & 0.1 & $\begin{array}{l}\text { Average of different VAR } \\
\text { specifications }\end{array}$ \\
\hline Romania & Stoian (2012) & 0.5 & 0.9 & \\
\hline Saudi Arabia & Espinoza and Senhadji (2011) & 0.3 & N/A & non-oil GDP \\
\hline Singapore & Tang and others (2010) & -0.2 & 0.5 & $\begin{array}{l}\text { Average of different VAR } \\
\text { specifications }\end{array}$ \\
\hline South Africa & Jooste (2012) & 0.3 & 0.7 & \\
\hline Thailand & Tang and others (2010) & -0.4 & 1.0 & $\begin{array}{l}\text { Average of different VAR } \\
\text { specifications }\end{array}$ \\
\hline ECCU & $\begin{array}{l}\text { Gonzales-Garcia and others } \\
\text { (2013) }\end{array}$ & 0.2 & 0 & panel \\
\hline GCC & Espinoza and Senhadji (2011) & 0.3 & $\mathrm{~N} / \mathrm{A}$ & panel, non-oil GDP \\
\hline Panel EMs & Ilzetzki (2011) & 0.2 & 0.3 & panel, 17 Ems \\
\hline Panel LICs & Kraay (2012) & 0.5 & $\mathrm{~N} / \mathrm{A}$ & $\begin{array}{l}\text { Public investment only; } 29 \\
\text { aid-dependent low-income } \\
\text { countries. Multiplier not } \\
\text { statistically significant. }\end{array}$ \\
\hline
\end{tabular}

Note: Unless otherwise noted, G denotes government investment and consumption multiplier, and T next taxes. If government consumption and investment multipliers are reported separately, we compute the simple average of the two. Short-term for most studies denotes first-year multipliers.

* $\mathrm{G}$ denotes government investment only. 


\section{Table A.3.2 Model-based Estimates of Short-Term Multipliers in EMEs and LICs}

\begin{tabular}{|c|c|c|c|c|c|c|c|}
\hline \multirow{2}{*}{$\begin{array}{l}\text { Study } \\
\text { Country }\end{array}$} & \multicolumn{2}{|c|}{ OECD (2009) } & \multicolumn{2}{|c|}{ GIMF } & \multicolumn{3}{|c|}{ Ducanes and others (2006) } \\
\hline & $\mathrm{G}^{*}$ & $\mathrm{~T}^{*}$ & $\mathrm{G}^{*}$ & $\mathrm{~T}^{*}$ & $\begin{array}{c}\mathrm{G} \\
\text { (increase) }\end{array}$ & $\begin{array}{c}\mathrm{G} \\
\text { (decrease) }\end{array}$ & $\mathrm{T}$ \\
\hline Bangladesh & & & & & 0.4 & 0.8 & 0.1 \\
\hline Bulgaria $^{1}$ & & & 0.6 & 0.4 & & & \\
\hline China & & & & & 0.3 & 1.6 & 0.4 \\
\hline Hungary & 0.5 & 0.1 & & & & & \\
\hline Indonesia & & & & & 0.2 & 0.8 & 0.2 \\
\hline Mexico & 0.7 & 0.2 & & & & & \\
\hline Philippines & & & & & 0.3 & 0.7 & 0.0 \\
\hline Poland & 0.6 & 0.2 & & & & & \\
\hline Russia & & & 0.8 & 0.3 & & & \\
\hline Turkey & 0.7 & 0.2 & 0.9 & 0.3 & & & \\
\hline $\begin{array}{l}\text { Emerging } \\
\text { Asia }^{2}\end{array}$ & & & 1.0 & 0.5 & & & \\
\hline
\end{tabular}

Note: Short-term refers to impact multipliers, which in DSGE models typically correspond to the first year.

*Averages of expenditure (excl. transfers) and tax instruments.

${ }^{1}$ Muir and Weber (2013) based on GIMF.

${ }^{2}$ Freedman and others (2009) based on GIMF. 


\section{REFERENCES}

Alesina, A., and R. Perotti, 1996, "Fiscal Adjustments in OECD Countries: Composition and Macroeconomic Effects,” NBER Working Papers 5730 (Cambridge: National Bureau of Economic Research).

Alesina, A., and S. Ardagna, 1998, "Tales of Fiscal Adjustment," Economic Policy, Vol. 13, No. 27, pp. 487-545.

- 2010, "Large Changes in Fiscal Policy: Taxes versus Spending," Tax Policy and the Economy, Vol. 24, pp. 35-68.

Anderson, D., B. Hunt, M. Kortelainen, M. Kumhof, D. Laxton, D. Muir, S. Mursula, and S. Snudden, 2013, "Getting to Know GIMF: The Simulation Properties of the Global Integrated Monetary and Fiscal Model," IMF Working Paper 13/55 (Washington: International Monetary Fund).

Anós-Casero, P., D. Cardero, and R. Trezzi, 2010, "Estimating the Fiscal Multiplier in Argentina," World Bank Policy Research Working Paper 5220 (Washington: World Bank).

Ardagna, S., F. Caselli, and T. Lane, 2007, "Fiscal Discipline and the Cost of Public Debt Service: Some Estimates for OECD Countries," B.E. Journal of Macroeconomics, Vol. 7, No. 1, pp. 28.

Auerbach, A.J., and Y. Gorodnichenko, 2012a, "Measuring the Output Responses to Fiscal Policy," American Economic Journal: Economic Policy, Vol. 4, pp. 1-27.

— 2012b, "Fiscal Multipliers in Recession and Expansion," in Fiscal Policy after the Financial Crisis, ed. by A. Alesina and F. Giavazzi, (Chigago: University of Chicago Press).

— 2013, “Output Spillovers from Fiscal Policy,” American Economic Review, Vol. 103, No. 3, pp. 141-6.

— , 2014, "Fiscal Multipliers in Japan," NBER Working Paper No. w19911 (Cambridge: National Bureau of Economic Research).

Barrell, R., D. Holland, and I. Hurst, 2012, "Fiscal Consolidation: Part 2. Fiscal Multipliers and Fiscal Consolidations," OECD Economics Department Working Paper No. 933 (Paris: Organization for Economic Co-operation and Development).

Barro, R. J., and C.J. Redlick, 2011, "Macroeconomic Effects from Government Purchases and Taxes," Quarterly Journal of Economics, Vol. 126, pp. 51-102. 
Batini, N., G. Callegari, and G. Melina, 2012, "Successful Austerity in the United States, Europe and Japan," IMF Working Paper 12/190 (Washington: International Monetary Fund).

Baum, A., M. Poplawski-Ribeiro and A. Weber, 2012, "Fiscal Multipliers and the State of the Economy," IMF Working Paper 12/286 (Washington: International Monetary Fund).

Baunsgaard, T. and S. A. Symansky, 2009, “Automatic Stabilizers: How Can They be Enhanced Without Increasing the Size of Government," IMF Staff Position Note 09/23 (Washington: International Monetary Fund).

Belhocine, N., and S. Dell'Erba, 2013, “The Impact of Debt Sustainability and the Level of Debt on Emerging Markets Spreads,” IMF Working Paper WP/13/93 (Washington: International Monetary Fund).

Blanchard, O., and R. Perotti, 2002, “An Empirical Characterization of the Dynamic Effects of Changes in Government Spending and Taxes on Output," Quarterly Journal of Economics, Vol. 117, pp. 1329-68.

Blanchard, O., and D. Leigh, 2013, "Growth Forecast Errors and Fiscal Multipliers," American Economic Review, Vol. 103, No. 3, pp. 117-20.

Born, B. F. Juessen, G.J. Mueller, 2013, "Exchange rate regimes and fiscal multipliers," Journal of Economic Dynamics and Control, Vol. 37, No. 2, pp. 446-65.

Botero, J., S. Djankov, R. Porta, and F. C. Lopez-De-Silanes, 2004, "The Regulation of Labor," The Quarterly Journal of Economics, Vol. 119, No. 4, pp.1339-82.

Canzoneri, M., F. Collard, H. Dellas, and B. Diba, 2012, "Fiscal Multipliers in Recessions," Discussion Papers, Department of Economics 12-04 (Bern: Universität Bern).

Christiano, L., M. Eichenbaum, and S. Rebelo, 2011, "When is the Government SpendingMultiplier Large?” Journal of Political Economy, Vol. 119, No. 1, pp. $78-121$.

Coenen, G.,C. J. Erceg, C. Freedman, D. Furceri, M. Kumhof, R. Lalonde, D. Laxton, J. Lindé, A. Mourougane, D. Muir, S. Mursula, C. de Resende, J. Roberts, W. Roeger, S. Snudden, M. Trabandt, and J. in't Veld, 2012, "Effects of Fiscal Stimulus in Structural Models," American Economic Journal: Macroeconomics, Vol. 4, No. 1, pp. 22-68.

Cole, H.L., and L.E. Ohanian, 2004, "New Deal Policies and the Persistence of the Great Depression: A General Equilibrium Analysis," Journal of Political Economy, Vol. 112, No. 4, pp. 779-816. 
Conway, P. and Orr, A., 2002, “The GIRM: A Global Interest Rate Model,” Westpac Institutional Bank Occasional Paper (Wellington: Westpac Institutional Bank).

Corsetti, G., A. Meier, and G.J. Müller, 2012, "What Determines Government Spending Multipliers?” IMF Working Paper WP/12/150 (Washington: International Monetary Fund).

Cloyne, J., 2013, "Discretionary Tax Changes and the Macroeconomy: New Narrative Evidence from the United Kingdom," American Economic Review, Vol. 103, No. 4, pp. 1507-28.

DeLong, B.J., and L.H. Summers, 2012, "Fiscal Policy in a Depressed Economy," presented to Brookings Papers on Economic Activity, March 2012.

Dolls, M., C. Fuest, and A. Peichl, 2012. "Automatic Stabilizers and Economic Crisis: US vs. Europe,” Journal of Public Economics, Vol. 96, pp. 279-94.

Ducanes, G., M.A. Cagas, D. Qin, P. Quising, and M.A. Razaque, 2006, "Macroeconomic Effects of Fiscal Policy: Empirical Evidence from Bangladesh, China, Indonesia, and the Philippines," Queen Mary, University of London Working Paper No. 564 (London: University of London).

Eggertsson, G., 2010, "What Fiscal Policy Is Effective at Zero Interest Rates?" NBER Macroeconomics Annual, Vol. 25, pp. 59-112.

Erceg, C. J., and J. Lindé, 2010, “Is There a Free Lunch in a Liquidity Trap?” International Finance Discussion Papers No. 1003 (Washington: U.S. Federal Reserve System).

European Commission, 2010, "Fiscal Policy, Debt Reduction, and Growth after the Crisis," chapter III of Public Finances in EMU (Brussels).

Espinoza, R., and A. Senhadji, 2011, "How Strong are Fiscal Multipliers in the GCC? An Empirical Investigation,” IMF Working Paper 11/61 (Washington: International Monetary Fund).

Estevão, M and I. Samake, 2013, "The Economic Effects of Fiscal Consolidation with Debt Feedback," IMF Working Paper 13/136 (Washington: International Monetary Fund).

Eyraud, L., and A. Weber, 2012, "Debt Reduction during Fiscal Consolidations: The role of Fiscal Multipliers," unpublished paper presented at the IMF surveillance meeting seminar of April 10, 2012.

— 2013, "The Challenge of Debt Reduction during Fiscal Consolidation," IMF Working Paper 13/67 (Washington: International Monetary Fund). 
Favero, C., and F. Giavazzi, 2012, "Measuring Tax Multipliers: The Narrative Method in Fiscal VARs," American Economic Journal: Economic Policy, Vol. 4, No. 2, pp. 69-94.

Fedelino, A., A. Ivanova, and M. Horton, 2009, “Computing Cyclically Adjusted Balances and Automatic Stabilizers,” IMF Technical Notes and Manuals. Forni, L., L. Monteforte, and L. Sessa, 2009, "The general equilibrium effects of fiscal policy: Estimates for the Euro area," Journal of Public Economics, Vol. 93 No. 3-4, pp.559-85.

Freedman, C., M. Kumhof, D. Laxton, and J. Lee, 2009, "The Case for Global Fiscal Stimulus," IMF Staff Position Note 09/03 (Washington: International Monetary Fund).

Ghosh, A., and L. Rahman, 2008, "The Impact of Fiscal Adjustment on Economic Activity" (Washington: International Monetary Fund, unpublished).

Giavazzi, F., and M. Pagano, 1990, "Can Severe Fiscal Contractions Be Expansionary? Tales of Two Small European Countries," NBER Macroeconomics Annual 1990, Volume 5, pp. $75-122$.

Gonzales-Garcia, J., A. Lemus, and M. Mrkaic, 2013, "Fiscal Multipliers in the ECCU," IMF Working Paper 13/117 (Washington: International Monetary Fund).

Gorodnichenko, Y., E.G. Mendoza, and L.L. Tesar, 2012, "The Finnish Great Depression: From Russia with Love", American Economic Review, Vol. 102, No. 4, pp. 1619-44.

Guajardo J., D. Leigh, and A. Pescatori, 2014, “Expansionary Austerity: International Evidence," Journal of the European Economic Association (forthcoming).

Hall, R. E., 2009, "By How Much Does GDP Rise If the Government Buys More Output?"Brookings Papers on Economic Activity, pp. 183-231.

Hayo, B. and Uhl, M., 2013, “The Macroeconomic Effects of Legislated Tax Changes in Germany," Oxford Economic Papers, 1of 22 (Oxford: Oxford University).

Hernández de Cos, P., and Moral-Benito, E., 2013, "Fiscal Multipliers in Turbulent times: The Case of Spain," Bank of Spain Working Paper 1309 (Madrid: Bank of Spain).

Ilzetzki, E., 2011, "Fiscal Policy and Debt Dynamics in Developing Countries," Policy Research Working Paper Series 5666 (Washington: The World Bank).

Ilzetzki E., E. G. Mendoza and C. A. Vegh, 2013, "How Big (Small?) Are Fiscal Multipliers?"Journal of Monetary Economics, Vol. 60, pp. 239-54. 
International Monetary Fund, 2008, World Economic Outlook, October, Chapter 5, "Fiscal Policy as a Countercyclical Tool," (Washington).

—_, 2010, World Economic Outlook, October, Chapter 3, "Will It Hurt? Macroeconomic Effects of Fiscal Consolidation," (Washington).

—_, 2011, World Economic Outlook, September, Chapter 4, "Separated at Birth? The Twin Budget and Trade Balances," (Washington).

—_, 2012, Fiscal Monitor, October (Washington).

__, 2013, "Guidance Note on Multipliers," (Washington, unpublished).

Jooste, C., 2012, "Analyzing the Effects of Fiscal Policy Shocks in the South African Economy," Department of Economics Working Paper 2012-06 (Pretoria: University of Pretoria).

Jorda O., and A.M. Taylor, 2013, "The Time for Austerity: Estimating the Average Treatment Effect of Fiscal Policy," Federal Reserve Bank of San Francisco Working Paper 2013/25 (San Francisco: U.S. Federal Reserve Bank).

Kraay, A., 2012, "How large is the Government Spending Multiplier? Evidence from World Bank Lending," Quarterly Journal of Economics, Vol. 127, No. 2, pp. 829-87.

Kirchner, M., J. Cimadomo and S. Hauptmeier, 2010, "Transmission Of Government Spending Shocks In The Euro Area: Time Variation and Driving Forces," ECB Working Paper Series 1219 (Frankfurt: European Central Bank).

Mehra, Y., 2001, "The Wealth Effect in Empirical Life-Cycle Aggregate Consumption Equations," FRB Richmond Economic Quarterly, Vol. 87, No. 2, pp. 45-68.

Mertens, R. and M. O Ravn, 2012, A Reconciliation of SVAR and Narrative Estimates of Tax Multipliers, CEPR Discussion Paper, No. 8973 (London: Center for Economic Policy Research).

_ 2013, "The Dynamic Effects of Personal and Corporate Income Taxes in the United States," American Economic Review, Vol. 103, pp. 1212-47.

Mineshima, A., M. Poplawski-Ribeiro, and A. Weber, 2014, "Fiscal Multipliers," in PostCrisis Fiscal Policy, ed. by C. Cottarelli, P. Gerson, and A. Senhadji (Cambridge: MIT Press, forthcoming).

Muir, D., and A. Weber, 2013, "Fiscal Multipliers in Bulgaria: Low But Still Relevant," IMF Working Paper 13/49 (Washington: International Monetary Fund). 
Organisation for Economic Co-operation and Development, 2009, "The Effectiveness and Scope of Fiscal Stimulus," OECD Economic Outlook Interim Report (Paris).

—, 2010, "Fiscal Consolidation: Requirements, Timing, Instruments and Institutional Arrangements" OECD Economic Outlook 2010/2 (Paris).

Owyang, M.T., V. A. Ramey, and S. Zubairy, 2013, “Are Government Spending Multipliers Greater During Periods of Slack? Evidence from $20^{\text {th }}$ Century Historical Data," NBER Working Paper 18769 (Cambridge: National Bureau of Economic Research).

Perotti, R., 2004, “Public Investment: Another (Different) Look,” IGIER (Innocenzo Gasparini Institute for Economic Research) Working Paper 277 (Bocconi: Bocconi University).

_ 2012, "The “Austerity Myth: Gain without Pain?” in Fiscal Policy after the Financial Crisis (Cambridge: National Bureau of Economic Research).

Rafiq, S., and A. Zeufack, 2012, "Fiscal Multipliers over the Growth Cycle: Evidence from Malaysia, World Bank Policy Research Working Paper 5982 (Washington: World Bank).

Ramey, V., 2011, “Identifying Government Spending Shocks: It's all in the Timing," Quarterly Journal of Economics, Vol. 126, No. 1, pp. 1-50.

Riera-Crichton, R., C. Veigh, and G. Vultein, 2012, “Tax Multipliers: Pitfall in Measurement and Identification,” NBER Working Paper No. 18497 (Cambridge: National Bureau of Economic Research).

Romer, C.D., and D.H. Romer, 2010, "The Macroeconomic Effects of Tax Changes: Estimates Based on a New Measure of Fiscal Shocks," American Economic Review, Vol. 100, pp. 763-801.

Romer, C.D., 2011, "What Do We Know About the Effects of Fiscal Policy? Separating Evidence From Ideology," Hamilton College, November 7, 2011.

Šimović, H. and M. Deskar-Škrbić, 2013. "Dynamic Effects of Fiscal Policy and Fiscal Multipliers in Croatia.” Journal of Economics and Business, Vol. 31, pp. 55-78.

Spilimbergo, A., S. Symansky, and M. Schindler, 2009, "Fiscal Multipliers," IMF Staff Position Note, SPN/09/11 (Washington: International Monetary Fund).

Stoian, A., 2012, “The Macroeconomic Effects of Fiscal Policy in Romania," Presentation. www.finsys.rau.ro/docs/Stoian\%20Anca.pdf. 
Tang, H. C., P. Liu, and E. C. Cheung, 2010, “Changing Impact of Fiscal Policy on Selected ASEAN Countries.” ADB Working Paper, No. 70 (Washington: Asian Development Bank).

Wang, X., and Y. Wen, 2013, "Is Government Spending a Free Lunch? — Evidence from China, Federal Reserve Bank of St. Louis Working Paper Series, Working Paper 2013-013A (St. Louis: U.S. Federal Reserve Bank).

Woodford, M., 2011, "Simple Analytics of the Government Expenditure Multiplier," American Economic Journal: Macroeconomics, Vol. 3, No. 1, pp.1-35. 